\title{
Dampak Pola Asuh Single parent Terhadap Tingkah Laku Beragama Remaja di Kabupaten Padang Lawas Utara
}

\author{
Desi Ratna Sari, Muhammad Amin \\ Alumni Jurusan BKI FDIK dan Dosen FDIK IAIN Padangsidimpuan.
}

\begin{abstract}
Abstrak
Keluarga single parent memiliki kewajiban membimbing anak, dalam menjalankan perannya secara sendirian membimbing anak menghadapi banyak kendala. Tulisan ini berawal dari hasil penilitian yang bertujuan untuk menggambarkan pola asuh orang tua single parent terhadap tingkah laku beragama remaja dan dampak pola asuh terhadap tingkah laku beragama remaja. Hasil penelitian menunjukkan bahwa pola asuh orang tua single parent menggunakan pola asuh demokratis dan pola asuh permissive berdampak positif pada perilaku keagaman anak terbukti dengan rajin melaksanakan ibadah, rajin membaca Alqurdan dan berbuat baik pada orang tua.
\end{abstract}

\begin{abstract}
Single parent families have an obligation to guide their children, in carrying out their role alone in guiding children to face many obstacles. This paper starts from the results of research that aims to describe the parenting style of single parents towards adolescent religious behavior and the impact of parenting on adolescent religious behavior. The results showed that parenting of single parent parents using democratic parenting and permissive parenting had a positive impact on the behavior of the diversity of children as evidenced by diligently practicing worship, diligently reading the Qur'an and doing good for parents.
\end{abstract}

\section{A. Pendahuluan}

Keberadaan keluarga dalam suatu masyarakat tidak terlepas dari peran seorang ayah dan ibu sebagai pendidik pertama bagi anakanaknya dalam bertingkah laku, baik di lingkungan keluarga maupun di lingkungan masyarakat. Orangtua mempunyai kewajibnan untuk mendidik anak-anaknya agar bertingkah laku dan memiliki akhlak yang baik sesuai dengan ketentuan yang diajarkan oleh Rasulullah sebagai suri tauladan bagi umat Islam.

Berbicara mengenai Islam berarti berbicara mengenai dakwah, karena dakwah merupakan ajaran menurut Islam, karena berdakwah juga mengandung arti mendidik manusia agar mereka bertingakah laku 


\section{Jurnal Kajian Gender dan Anak}

Vol. 03 No. 1 Juni 2019

Pusat Studi Gender dan Anak IAIN Padangsidimpuan

sesuai dengan niali-nilai kejujuran, keimana, kedislplinan, kasih sayang dan nilai akhlak mulia lainnya. (Faizah dan Muhsin Efendi, 2006: xii) Nilai-nilai inilah yang akan diajarkan oleh orangtua sebagai guru pertama di dalam keluarga.

Menjadi orangtua merupakan salah satu dari banyak tugas manusia sebagai makhluk sosial. (Kartini Kartono, 2003 : 34). Orangtua merupakan guru pertama bagi anak-anaknya, terutama dalam menanamkan nilai-nilai agama yang baik dalam kehidupan sehari-hari. Orangtua sebagai penanggung jawab pendidikan dalam lingkungan keluarga, menempati posisi penting dalam pandangan Islam, oleh sebab itu orangtua mempunyai tugas yang sangat penting dalam lapangan pendidikan.

Fakta-fakta yang terdapat di masyarakat, banyak terjadi kasus perceraian, yang dapat diketahui melalui pemberitaan media televisi dan media sosial lainnya. Perceraian merupakan jalan yang ditempuh oleh banyak orang dalam menyelesaikan permasalahan yang terjadi. Perceraian sudah hal yang lumrah dan biasa menurut mereka, akibatnya anak-anak menjadi korban keegoisan kedua orangtuanya. Padahal anak seharunya membutuhkan perhatian dan kasih sayang dari kedua orang tuanya.

Peristiwa perceraian dalam keluarga senantiasa membawa dampak mendalam, dan kasus ini menimbulkan stress, tekanan dan perubahan fisik dan mental (Save M. Dagun, 2002:113). Dari pendapat tersebut dapat difahami bahwa dampak yang diakibatkan perpisahan yang terjadi antara orangtua di dalam keluarga, sehingga melahirkan masalah lain dalam keluarganya. Namum dampak tersebut tidak semua mengarah kepada dampak negatif, akan tetapi juga bisa berdampak positif. Dampak negatif misalnya pengaruh yang kuat yang mendatangkan akibat, yakni dampak negatif dari single parent, seperti perubahan tingkah laku pada anak, sehingga bisa menjadi anak pemarah, 
berkata kasar, suka melamun dan lain-lain. Dampak positif seperti terhindar dari pertengkaran orangtua, lebih mandiri dan berpribadi kuat.

Masalah yang diakibatkan dari orangtua single parent dan tingkah laku beragama remaja dalam kehidupan sehari-hari memang beragam, tidak semua pola asuh yang diberikan oleh orangtua single parent berakibat negatif terhadap tingkah laku beragama dalam hal rutinitas shalat, membaca Alqur,an dan berbuat baik kepada orang tua single parent, terkadang anaknya tidak mau mendengarkan perintah oleh orangtua single parent.

Disamping dampak negatif juga terdapat dampak positif dari salah satu keluarga yang diobservasi keluarga single parent tersebut termasuk ke dalam salah satu keluarga single parent yang sukses mendidik anggota keluarganya.

Walaupun tidak semua tingkah laku anak single parent buruk, tetapi masalah inilah yang akan diteliti, apakah tingkah laku remaja bermasalah tersebut diakibatkan dampak pola asuh single parent atau memang remaja tersebut memang tidak bisa terdidik dengan baik.

Maka dianggap penting untuk diteliti tentang dampak pola asuh single parent terhadap keberagamaan remaja yang ditujukan untuk mengetahui pola asuh orang tua single parent terhadap keberagaam remaja, untuk mengetahui dampak positif dan negatif pola asuh single parent terhadap remaja, dan untuk mengetahui solusi yang diperlukan terhadap tingkah laku beragama anak.

Peneilitian ini diharapkan dapat berkontribnusi pada bidang kajian gender dan bidang keilmuan bimbingan konseling dan dapat menambah informasi bagi single parent mengenai pola asuh terhadap tingkah laku beragama remaja dalam kehidupan sehari-hari. 


\section{Jurnal Kajian Gender dan Anak}

Vol. 03 No. 1 Juni 2019

Pusat Studi Gender dan Anak IAIN Padangsidimpuan

\section{B. Kajian Pustaka}

\section{Dampak}

Dampak adalah pengaruh dari suatu peristiwa yang terjadi dan dapat berakibat positif atau negatif. Dalam setiap keputusan yang diambil oleh seseorang atasan biasanya mempunyai dampak tersendiri, baik itu dampak positif maupun dampak negatif. Namun dalam tulisan ini dampak dimaksud adalah dampak negatif dan dampak positif yang ditimbulkan oleh single parent terhadap anaknya, bagiamana pola asuh yang dilakukan oleh single parent dalam mendidik anaknya.

Dampak negatif single parent adalah perubahan perilaku anak. Seorang anak yang ditinggalkan orang tuanya bisa mengakibatkan perubahan tingkah laku, menjadi pemarah, berkata kasar, suka melamun, suka memukul, menendang dan juga menyakiti orang lain. Anak juga tidak berkesempatan memiliki dan merasakan bagaimana keluarga yang harmonis, dampak yang paling berbahaya, apabila anak mencari pelarian di luar rumah, seperti menjadi anak jalanan, terpengaruh narkoba, minum minuman keras, merokok dan sebagainya untuk melenyapkan kegelisahan dalam hatinya, terutama anak yang kurang kasih sayang dan kurang perhatian dari kedua orangtuanya. Tingkah laku anak yang bermasalah dan melakukan kenakalan remaja merupakan cerminan dari gaya hidup keluarga yang sakit atau kacau. (Kartini Kartono,2010:62)

Selain dampak negatif, juga terdapat dampak positif yakni anak akan terhindar dari komunikasi kontradiktif orang tua, tidak akan terjadi komunikasi yang berlawanan dari orangtua, misalnya ibunya mengijinkannya tetapi ayahnya melarang. Nilai yang diajarkan oleh ibu diterima penuh karena tidak terjadi pertentangan. Kemudain ibu atau ayah berperan penuh dalam pengambilan keputusan yang tegar. Kemudian anak lebih mandiri dan semakin tangguh, karena terbiasa tidak selalu didampingi, terbiasa menyelesaikan berbagai masalah kehidupan sendiri.

Selanjutnya terdapat faktor-faktor yang mempengaruhi dampak internal dan eksternal single parent yakni dampak terhadap ayah/ibu seperti beban ekonomi, kemiskinan, hal tersebut jelas berdampak terhadap 
kehidupan dan perekonomian keluarga. (Sofyan Wilis,2009:15). Seorang ayah maupun ibu yang menjadi single parent otomatis merasa terbebani dan memiliki resiko yang besar dalam mengurus anak-anaknya, terlebih jika keadaan ekonomi mereka rendah. Single parent mau tidak mau harus menafkahi anak-anaknya demi kelangsungan hidup mereka sehari-hari.

Disamping itu Single parent juga kurang bisa melindungi anaknya dari gangguan orang lain dan dalam jangka panjang, maka akan menimbulkan kecemasan pada anak atau gangguan psikologis yang sangat berpengaruh pada perkembangan anak. (Sofyan Wilis,2009:16)

\section{Pola Asuh Orang Tua}

Pola asuh dan penerimaan masyarakat yang positif pada anak single parent akan menghilangkan image bagi anak yang terkesan sebagai makhluk lemah. Single parent dapat dilihat dalam beberapa segi, antara lain cara single parent menetapkan aturan dan kedisplinan, pemberian hukuman dan ganjaran, juga cara single parent menampilkan kekuasaannmya serta cara memberi perhatian terhadap keinginan anaknya. Adanya kesadaran pengasuhan yang tinggi akan mendorong orangtua untuk melakukan tugastugas sebaik mungkin sehingga kesejahteraan anak tercapai. (Sri Lestari,2012:66)

Secara kodrati ibu dan bapak diberikan anugrah oleh Tuhan Pencipta berupa naluri orang tua. Karena naluri itu timbul rasa kasih sayang pada orangtua kepada anak-anak mereka, sehingga secara moral keduanya, merasa terbebani tanggung jawab untuk memelihara, mengawasi, melindungi serta membimbing keturunan mereka. (Jalaluddin,2010:294).

Jadi pola asuh single parent adalah bagaimana cara single parent untuk merawat dan mendirik anak-anaknya untuk tumbuh dan berkembang menjadi anak yang baik, sholeh dan sholehah, bahagia di dunia dan akhirat, sesuai dengan ajaran agama Islam dan berbakti kepada ibu yang memiliki resiko ganda untuk bertanggung jawab dalam mendidik, mengasuh dan mengarahkan anak-anaknya dalam bertingkah laku yang baik di tengahtengah keluarga dan masyrakat. 


\section{Jurnal Kajian Gender dan Anak}

Vol. 03 No. 1 Juni 2019

Pusat Studi Gender dan Anak IAIN Padangsidimpuan

\section{Macam pola asuh orangtua}

Bentuk pola asuh orangtua terhadap anaknya pada dasarnya dapat membantu dalam mengembangkan kontrol diri sehingga anak dapat mengambil keputusan-keputusan yang tepat dalam berperilaku. Berkenaan dengan model teori pola asuh orangtua setidaknya ada tiga macam bentuk yaitru : pertama pola asuh menang atau otoriter, dalam pola asuh ini menekankan aturan orangtua harus ditaati oleh anak, orangtua bertindak semena-mena tanpa dapat dikontrol oleh anak.(Agoes Dariyo,2004:97). Dalam hal ini akan harus menurut dan tidak boleh membantah terhadap apa yanng diperintahkan orang tua. Pola asuh ini mempunyai ciri orangtua bertindak tegas pada anaknya, suka menghukum, kurang memiliki kasih sayang dan kurang simpati.

Kedua pola asuh mengalah atau permissive, dalam pola asuh ini orang tua selalu bersikap menuruti apa yang menjadi keinginan anak. Bentuk pola asuh ini akan menjadikan anak menjadi manja, sedangkan sikap orang tua cenderung melindungi anak secara berlebihan. (Agoes Dariyo,2004:98). Ciri-ciri pola asuh ini antara lain orang tua memberikan kebebasan kepada anak, orangtua memberikan kasih sayang cenderung sangat longgar, anak tidak dituntut untuk bertanggung jawab, anak diberikan kebebasan dan orang tua tidak banyak mengatur dan mengkontrol.

Ketiga pola asuh tidak menang dan tidak kalah atau demokratis, pola asuh ini merupakan pola asuh yang kedudukan orang tua akan seimbang. Suatu keputusan diambil bersama dengan mempertimbangkan kedua belah pihak. Konflik diselesaian tanpa ada salahnya satu yang menang ataupun kalah, karena penyelesaian dapat diterima oleh kedua belah pihak.

Keempat pola asuh menurut Islam, diawali dengan uraian bahwa dalam syariat Islam mendidik dan membimbing anak merupakan suatu kewajiban bagi seorang muslim karena anaknya merupakan amanat yang harus dipertanggungjawabkan oleh orang tua. Imam Al Ghazali mengatakan anak adalah amanat di tangan kedua orangtuanya, hatinya yang suci yang masih mentah, belum dipahat maupun dibentuk. Mutiara ini dapat dipahat 
dan dibentuk apapun, mudah condong kepada segala sesuatu. Apabila dibiasakan dan diajari denghan kebaikan, maka dia akan tumbuh dalam kebaikan itu. (Muhammad Nur Abdul Hafizh Suwaid,2010:46).

Pendadat ini bermakna bahwa anak dalam keluarga merupakan generasi muda Islam di masa mendatang, apabila orangtuanya mampu memberikan pendidikan dan latiahn-latihan utnuk pengamalan agama di dalam kehidupan sehari-hari. Pendidikan dalam Islam mengajarkan pola asuh yang dilakukan orangtua juga mencakup bagaimana orang tua mampu membentuk akhlakul karimah terahdap anak-anaknya.

Selanjutnya menurut perfektif Islam mengasuh dan mendidik anak dapat ditempuh dengan beberapa cara yaitu : pertama pendidikan ketedalanan, suri tauladan yang baik memiliki dampak yang besar pada keperibadian anak. (Muhammad Nur Abdul Hafizh Suwaid,2010:139), sebab mayoritas yang ditiru anak berasal dari kedua orangtuanya. Memberikan ketedalanan yamg baik merupakan metode pendidikan yyang terbaik yang paling membekas kepada anak. Keteladanan seorang anak biasanya mencerminkan keteladan orangtuanya.

Kedua pendidikan dengan pembiasaan sejak kecil, konsep kebiasaan anak sebenarnya harus diaplikasikan dan ditanamkan oleh orangtua kepada anaknya sejak kecil sehingga anak akan terbiasa dan menerapkan proses pembiasaan yang baik yang diajarkan oleh orangtuanya. Hal inni sesuai yang dijelaskan oleh Sayyid Sabiq, metode pengajaran dan pembiasaan ini merupakan prinsip utama dalam pendidikan sehingga nantinya menjadi suatu kebiasaan pada diri anak dan tidak akan tergoyahkan. Serta merupakan metode paling efektif dalam pembentukan kebaikan dan pendidikan akhlak anak shalih. (Sayyid Sabiq,1998:28)

Ketiga pendidikan dan nasehat, pendidikan dengan cara memberikan nasehat, perhatian atau pengawasan dalam proses mendidik anak mempunyai ciri-ciri tersendiri sedangkan cara seruan yang menyenangkan diiringi dengan kelembutan. Metode ini mempunyai pengaruh yang cukup besar terhadap jiwa dan perasaan. Seruan yang menyenangkan disertai kelembutan akan lebih mudah diterima. 


\section{Jurnal Kajian Gender dan Anak}

Vol. 03 No. 1 Juni 2019

Pusat Studi Gender dan Anak IAIN Padangsidimpuan

Pola asuh selanjutnya dalam perhatian terhadap keimanan anak, hal ini yang paling penting yang harus ditanamkan orangtua terhadap anak adalah bagaimana anak mampu menginternalisasikan iman mereka dan mewujudkannya dalam perilaku. (Kusdwiratri Setiono,2011:140)

Selanjutnya perhatian terhadap moral anak, perhatian terhadap kejiwaan, perhatian kepada segi sosial anak, memberi hadiah dan memberi hukuman. Memberikan hadiah mirip dengan pemberian pujian, tetapi ada bedanya, memberikan pujian diberikan ketika anak bertingkah laku positif, sedangkan memberikan hadiah ditujukan untuk memancing timbulnya perilku positif. (Muhammad Nur Abdul Hafizh Suwaid, 2010:141).

Pemberian hukuman bukanlah pembalasan dendam kepada anak, tujuan sebenarnya adalah pendidikan dan merupakan salah satu metode pendidikan. Hukuman diberikan apabila larangan dan perintah tidak diindahkan, tidak dilaksanakan dan tidak dipatuhi. Hukuman merupakan cara yang terakhir digunakan apabila cara-cara lain tidak bisa digunakan lagi.

\section{Persfektif Islam Terahadap Single parent}

Single parent berasal dari Bahasa Inggris yang diartikan single yaitu tunggal atau sendirian (John M.Echols dan Hasan Shadly,1976:258), tidak beristri dan juga tidak bersuami. Sedangkan parent yaitu orangtua, orang tua di sini bisa ayah atau ibu saja. Jadi yang dimaksud dalam tulisan ini dengan single parent adalah orangtua yang tinggal dalam rumah tangga yang hanya sendirian saja, bisa ibu atau bapaik saja (tidak beristri dan juga tidak bersuami.

Single parent inilah yang pada akhirnya harus bertanggung jawab sendirian dalam mendidik, menjaga dan memelihara dan membantu kebutuhan jasmani dan rohani anak-anaknya dalam kehidupan sehari-hari agar perkembangan dan pertumbuhan anak-anaknya tidak terkendala sehingga anak tersebut merasa diperhatikan dan tidak diacuhkan.

Pakar lain berpendapat bahwa permasalahan ibu rumah tangga di Malaysia telah membagikan status ibu tunggal kepada lima kategori yaitu pertama wanita yang kematian suami, wanita yang berpisah (sedang dalam 
proses perceraian), wanita yang ditnggal suami (suami menghilangkan diri), wanita yang tidak berkahwin, tetapi mempunyai anak, dan wanita yang diceraiakan.(Zainab Ismail,2010:158)

Islam merupakan agama yang menitik beratkan kebahagian hidup pasangan suami istri. Perkawinan dan rumah tangga dalam Islam adalah perkara utama yang dijadikan tumpuan dalam usaha memelihara, mengekal dan mempertingkatkan keharmonisan. Oleh karena itu perkawinan mempunyai kaitan dengan personal kasih sayang yang berlandaskan hati dan perasaan yang senantiasa ada pasang surutnya, maka perceraian adalah salah satu hal yang tidak dapat dielakkan.

Meskipun demikian Islam berusaha sebelum menjatuhkan pilihan berpisah dan bercerai mengatasi permasalahan ini sesuai dengan langkahlangkah yang diajarkan. Hal itu sebagai langkah terakhir jika tidak diperoleh manfaat dan semua pintu islah telah tertutup serrta mengharuskan bercerai/talak, mau tidak mau langkah ini harus ditempuh. (Syaikh Abdul Muin,2011:14)

\section{Tingkah laku Beragama Remaja}

Tingkah laku beragama adalah suatu perbuatan yangh dilakukan oleh seseorang. Tingkah laku beragama merupakan perbuatan dalam beribadah yang dilakukan oleh sesorang dari kehidupan keagamaan meliputi pengalaman-pengalaman untuk melaksanakan ajaran-ajaran Islam ayang merupakan perintah Allah SWT untuk melaksanakan tingkah laku beragama (Zakiyah Darajad,1991:72)

Orangtua melalui cara yang dilakukannya dapat memberikan dampak bagi perkembangan tingkah laku remaja. Perkembangan tersebut satu-satunya meliputi tingkah laku beragama remaja. Orangtua berperan dalam memberikan motivasi, informasi dan penguatan bagi tingkah laku beragama remaja. Melalui fungsi informasi remaja memperoleh materi yang akan mempengaruhi pemahamamhnya akan nilai-nilai agama. Sedangkan melalui fungsi motivasi dan penguatan anak memperoleh dukungan eksternal atas segala tingkah laku beragama anak. 


\section{Jurnal Kajian Gender dan Anak}

Vol. 03 No. 1 Juni 2019

Pusat Studi Gender dan Anak IAIN Padangsidimpuan

\section{Metodologi}

Penelitian ini dilaksanakan di Kabupaten Padang Lawas Utara, dengan metode kualitatif deskriptif, dari data yang diamati dan diwawancarai di lapangan. Informan penelitian ini adalah 8 (delapan) single parent dan 15 (lima belas) remaja anak single parent. Sumber data skunder diperoleh anggota masyarakat desa Trans Batang Pane Kabupaten Padang Lawas Utara. Pengumpulan data dilakukan melalui wawancara terhadap 8 informan single parent dan 15 remaja single parent dan observasi terhadap pola asuh single parent terhadap anakanaknya. Data yang diperoleh dari lapangan selanjutnya dianalisis dan disimpulkan sebagai temuan dari penelitian. Dalam menganalisa data yaitu bersifat khusus, kemudian ditarik kesimpulan yang berlaku umum. Data-data yang sudah terkumpul dibahasakan, ditafsirkan secara induktif sehingga dapat diberikan gambaran mengenai hal-hal yang sebenarnya terjadi (Wina Sanjaya,2009:86)

\section{Hasil Penelitian}

Informasi yang didapatkan tentang keadaan single parent yang ada di desa Trans Batang Pane II memang cukup unik, ternyata tidak semua single parent yang diwawancarai dan observasi mengeluh dengan keadaannya sebagai single parent. Sebagian dari single parent menganggap bahwa hidup menjadi sebagai single parent adalah takdir yang diberikan Allah SWT dan harus dijalani, karena memang hakikat manusia adalah sebagai hamba dan Khalifah dimuka bumi, yang ditugaskan hanya untuk mengemban amanat menjalankan ibadah yang diperintahkan Allah, selebihnya kita serahkan kepada Allah karena memang suatu saat pasti semua makhluk akan kembali kepadanya.

Berbeda dengan single parent lainnya, jika sebagaian dari single parent tidak merasa terbebani dengan statusnya sebagai single parent yang megurus rumah tangga sendiri, sebagaian single parent justru malah merasa terbebani dengan status single parent tersebut, alasannya karena kesibukan kerja untuk menafkahi anak-anaknya dan cara membimbing anak mereka di rumah tidak 
dapat terjalankan dengan baik sesuai keinginan, karena kenyataannya sebagian single parent justru lebih mementingkan pekerjaan mereka dalam mencari nafkah demi kebutuhan keluarganya khususnya anak-anaknya.

a. Temuan Khusus.

1. Pola Asuh Single parent Terhadap Tingkah Laku Beragama Remaja

a) Pola Asuh Pada Rutinitas Sholat.

Sholat merupakan kewajiban yang tidak bisa dipungkiri sebagai seorang muslim yang beriman karena sholat merupakan hal yang urgent. Sholat merupakan komunikasi hamba dengan Tuhan, semakin kuat komunikasi tersebut maka semakin kukuh keimanan seseorang. Tingkah laku beragama remaja dalam hal rutinitas menjalankan ibadah sholat lima waktu dalam kehidupan sehari-hari pasti tidak terlepas dari peran single parent, baik itu sosok seorang ibu ataupun seorang ayah yang tinggal sendiri mengurus segala urusan keluarga, sedikit banyaknya single parent harus selalu memperhatikan, membimbing dan melatih anaknya dalam ibadah sholat, khususnya usia remaja.

Berikut hasil wawancara penulis dengan bapak Jafar, salah satu single parent di desa Trans Batang Pane II Blok A, mengenai pola asuh yang diberikan beliau dalam aktivitas sholat kepada anaknya,beliau mengatakan bahwa:

Dari dulu saya mendidik anak dengan cara menanamkan kedisiplinan, terutama dalam membimbing anak dalam menjalankan ibadah sholat, karena sholat merupakan benteng pertahanan diri, saya suka marah jika mereka tidak mengerjakan sholat, sehingga anak-anak saya sudah biasa sholat tanpa disuruh, saya termasuk orang yang keras dan tegas dalam mendidik anak-anak saya, saya tidak ingin anak saya menjadi orang yang manja, karena anak sekarang kalau dimanja makin berani dan menganggap remeh orang tua. Sehingga mereka selalu menurut perintah saya apabila saya menyuruh mereka, tidak berani berkata kasar kepada saya.

Dari hasil wawancara tersebut, dapat dipahami bahwa pola asuh yang diberikan bapak Jafar kepada anaknya adalah bentuk pola asuh otoriter, yaitu tegas dalam membimbing anaknya untuk sholat, adapun alasan beliau untuk menggunakan pola asuh otoriter kepada 


\section{Jurnal Kajian Gender dan Anak}

Vol. 03 No. 1 Juni 2019

Pusat Studi Gender dan Anak IAIN Padangsidimpuan

anaknya karena beliau tidak ingin anaknya manja, berani dan melunjak kepada orang tua, selalu membiasakan diri hisup disiplin, rajin beribadah agar menjadi anak yang dapat membantu orang tuanya kelak dan bertanggung jawab, karena setiap perbuatan yang dilakukan oleh manusia harus dipertanggung jawabkan oleh diri sendiri.

Setelah penulis mewawancarai bapak Jafar, penulis mengobservasi pola asuh otoriter yang dilakukan beliau terhadap anaknya yaitu Rina dan Rika dalam rutinitas sholat terlihat bahwa anak beliau rajin dalam mengerjakan sholat lima waktu. Berikut hasil wawancara dengan Rina anak bapak Jafar, Rina mengatakan bahwa:

Bapak tegas dalam mendidik saya, selalu menyuruh sholat dan mengajarkan saya dalam bertingkah laku yang baik, mengajarkan bagaimana cara menghargai dan menghormati orang yang lebih tua, bahkan jika saya tidak menuruti perintahnya saya dinasehati, bahkan diancam tidak diberi uang. Jadi saya selalu menuruti perintah ayah, walaupun kadang saya merasa enggan ketika disuruh, tetapi saya tahu itu demi kebaikan saya, sehingga saya menuruti dan akhirnya menjadi kebiasaan

Saat mewawancari bapak Ade, beliau menyatakan hal yang sama sebagai berikut:

"bapak menyuruh anak dapat rutin sholat dan mengaji setiap selesai sholat subuh dan sholat magrib ke tempat ibu Rohimah, agar tidak seperti bapak, bapak ingin anak bapak menjadi anak yang pintar dan rajin dalam beribadah, apalagi sholat wajib."

Hasil wawancara penulis dengan bapak Ade juga memiliki penuturan yang sama dengan bapak Jafar sebelumnya, keduanya sama-sama menggunakan pola asuh otoriter dalam rutinitas sholat. Sedangkan bapak Ade mengatakan jika mereka tidak mau disuruh beribadah, contohnya sholat dan mengaji, siapa yang akan mendoakan kami, karena itu tujuan kita mempunyai anak, supaya ada yang mendoakan dan menghormati dan membantu orang tuanya, itulah alasan yang dikatakan oleh ketiga single parent saat diwawancarai. 
Berbeda dengan hasil wawancara yang diuraikan sebelumnya, ibu Nyaminem menurutkan bahwa: " Ibu selalu menyarankan anak ibu untuk sholat, akan tetapi ibu tidak mengetahui apakah dia melaksanakan sholat atau tidak, karena ibu sendiri selalu bekerja setiap hari, ketika anaknya tidak mengerjakan sholat, ibu selalu memberikan nasihat agar mereka mengerjakan sholat dengan teratur"

Sehubung dengan hasil wawancara yang telah diuraikan berdasarkan hasil wawancara dengan ibu Nyaminem, hasil wawancara dengan bapak Jodi memiliki kesamaan, beliau menuturkan bahwa: " saya kurang tahu bagaimana kegiatan anak saya sehari-harinya, sholat atau tidak, karena saya setiap hari bekerja dan hanya bisa mengarahkan dengan menyuruh anak saya untuk mengerjakan sholat"

Setelah mewawancarai single parent, penulis mengobservasi 8 keluarga single parent terhadap tingkah laku beragama remaja dalam rutinitas sholat lebih banyak yang menggunakan pola asuh otoriter demokratis, maksudnya single parent memang menyuruh anak-anaknya mengerjakan sholat, tetapi dalam batasan yang yang sewajarnya, artinya tidak sampai menyakiti remaja apabila tidak mendengarkan apa yang disampaikan single parent,(Observasi: 1704) alasannya karena single parent tidak ingin anaknya merasa terkekang, cukup rutin mengingatkan dan memberikan pemahaman kepada remaja bahwa sholat itu penting, jika memang remaja mengerti, pasti dikerjakan, tetapi sebaliknya dipaksakan jika memang remajanya bandel tidak ada gunanya. (Wawancara: 1404).

Berbeda dengan hasil wawancara dengan bapak Jafar, dan Bapak Ade, 3 single parent itu justru berbeda, mereka tidak segan menghukum dan mengancam anak-anak mereka jika anak mereka tidak mau disuruh sholat, alasannya mereka menganggap remaja sekarang harus selalu dikontrol pergaulannya dan tingkah lakunya 


\section{Jurnal Kajian Gender dan Anak}

Vol. 03 No. 1 Juni 2019

Pusat Studi Gender dan Anak IAIN Padangsidimpuan

agar tidak terpengaruh pergaulan teman-temannya, dan juga harus dibiasakan disiplin dalam menjalankan ibadah, salah satunya sholat.

Berdasarkan hasil wawancara yang dilakukan mengenai pola asuh yang dilakukan keluarga single parent terhadap tingkah laku beragama dalam rutinitas sholat adalah 8 single parent yang menggunakan pola asuh otoriter dalam rutinitas sholat adalah 3 orang, yaitu bapak Jafar, Ibu Elly dan bapak Ade, sedangkan pola asuh single parent terhadap tingkah laku beragama remaja dalam rutinitas sholat yang bersifat demokratis, yaitu ada 5 orang yaitu Ibu Miati, ibu Nyamiem, Bapak Dodi, Ibu Yanti dan ibu Rohati.

b) Pola Asuh Dalam Membaca Al-Quran

Membaca Al-Quran termasuk amalan yang sangat mulia dan Allah menjanjikan pahala yang berlipat ganda bagi yang melakukannya meskipun tidak mengerti makna atau artinya. AlQuran merupakan petunjuk bagi orang-orang beriman dan bertakwa. Di dalam Al-Quran terdapat rahmat yang besar dan pelajaran bagi orang-orang beriman. Al-Quran juga merupakan petunjuk yang dapat mengeluarkan manusia dari kegelapan menuju jalan yang terang. Oleh karena itu penulis membahas masalah pola asuh single parent terhadap tingkah laku beragama remaja salah satunya mengenai membaca Al-Quran, karena penulis melihat begitu banyaknya manfaat membaca Al-Quran namun masih ada sebahagian remaja dari keluarga single parent yang tidak mau membaca Al-Quran. (Observasi: 10-1402).

Hasil wawancara penulis terhadap keluarga single parent di desa Trans Batang Pane II yaitu bapak Ade yang dijumpai di rumahnya, bapak tersebut menyatakan: "orang tua yang tidak dapat membaca Al-Quran selalu menyuruh anak-anaknya rutin sholat dan mengaji, oleh karena itu bapak selalu menyuruh anak untuk mengaji selesai sholat subhu dan magrib ke rumah ibu Rohimah agar tidak seperti bapak. Bapak ingin anak-anak bapak pintar dan rajin dalam beragama, apalagi sholat dan mengaji" (Wawancara: 1404). 
Sehubungan dengan itu, penulis juga mewawancarai bapak Jafar menggunakan pola asuh yang berbeda, beliau menuturkan bahwa: "jika membaca Al-Quran memang bapak kurang tegas, tidak setegas saat menyuruh Rina dan Rika Sholat, karena bapak kurang lancer membaca Al-Quran. Almarhum ibunya Rina yang suka menyuruh dan mengajari mereka, tetapi setelah meninggal tidak ada lagi yang mengajari anak-anak selain hanya belajar di sekolah. (Wawancara: 1704)

Selain wawancara, penulis juga melakukan observasi mengenai pola asuh single parent menggambarkan bahwa menyuruh anak remajanya membaca Al-Quran memang kurang, bahkan ada yang sama sekali tidak pernah menyuruh anaknya untuk mengaji, seperti menjelang dan seusai sholat magrib. Anakanak single parent masih banyak yang sibuk dengan acara sinetron di televisi.

Pola Asuh keluarga single parent di Desa Trans Batang Pane II kepada keluarga single parent mengenai pola asuh yang mereka berikan terhadap tingkah laku beragama remaja dalam membaca AlQuran yaitu lebih banyak yang menggunakan pola asuh permissive. Dari 8 keluarga, hanya dua single parent yang menggunakan pola asuh otoriter, yaitu bapak Ade dan Ibu Elly.

Selain itu Bapak Jafar menggunakan pola asuh demokratis, alasannya karena single parent tidak lancar dan tidak terbiasa mengajari mengaji, yang biasa mengajarkan anaknya mengaji adalah almarhum istrinya. 5 single parent lainnya menggunakan pola asuh Permissive, alasannya, karena selain kerja dan capek dalam mengurus segala kebutuhan rumah, sebagaian anak dari keluarga single parent juga bandel, tidak penurut, sehingga single parent bosan jika selalu menyuruh dan marah-marah tetapi sang anak tidak mau mendengarkan. 


\section{Jurnal Kajian Gender dan Anak}

Vol. 03 No. 1 Juni 2019

Pusat Studi Gender dan Anak IAIN Padangsidimpuan

c) Pola Asuh Berbuat kepada orang tua

Keharusan seorang anak berbuat baik kepada orang tua tunggal sudah pasti menjadi kewajiban seorang anak, sebagai bentuk kasih saying kepada orang tua yang susah payah mengurus anaknya mulai dari mengandung sampai menyapih selam 2 tahun. Namun tidak semua remaja mengetahui dan faham perihal tersebut. Terkadang remaja masih berani membentak dan berbicara kurang sopan kepada orang tuanya. Hal ini dijelaksn oleh ibu Rohati, beliau menuturkan bahwa:" anak-anak sekarang tidak berfikir, jika disuruh banyak alasan, padahal untuk kebaikan dirinya sendiri, jika dikasih tau malah melawan, suatunya lebih tinggi, ibu tidak tahu bagaimana cara menasihatinya"

Berdasarkan observasi, kepada anak ibu Rohati yaitu Rahmad, penulis Rahmad tidak pulang ke rumah, Rahmad mengaku tidak pulng, krena tidak diberikan hp oleh orang tuanya. Alasan Rahmad meminta HP karena teman-temannya banyak yang memiliki hp sehingga Rahmad meminta ibunya untuk dibelikn hp, tanpa melihat keadaan orang tuanya.

Berdasarkan hasil wawancara terhadap 8 keluarga single parent mengenai pola asuh terhadp tingkah laku beragama remaja dalam berbuat baik kepada orang tu tunggal adalah lebih banyak yang menggunakan pola asuh permissive. Tiga orang single parent menggunakan pola asuh demokrastis dalam berbuat baik kepad orang tua, alasnnya karena menurut informan selain belajar di sekolah, berbuat baik kepd orang tua tunggal, diingatkan agar remaja mampu menghormati orang tunya. 5 single parent yang lain menggunakan pola asuh permissive, alasannya sudah terlanjur sudah memanjakan mereka dari awal, sehingga remaja tidak takut kepada orang tua. 
2. Dampak Pola Asuh Single parent Terhadap Tingkah Laku Beragama Remaja

a. Dampak Pola Asuh Pada Rutinitas Sholat.

Pola Asuh Single parent dalam rutinitas menjalankan Ibadah Sholat pada diri remaja pasti perperan penting. Bagaimana cara single parent membimbing remaja agar selalu rutin dalam menjalankan sholat 5 waktu, adapun dampak pola asuh otoriter yang diberikan oleh single parent terhadap tingkah laku remaja dalam rutinitas sholat adalah remaja semakin rajin dan terbiasa mengerjakan ibadah sholat tanpa harus disuruh, seperti apa yang disampaikan salah satu informan penelitian, Rina anak pak Jafar:"Bapak tegas dalam mendidik kami, selalu menyuruh untuk sholat, dan mengajarkan kami dalam bertingkah laku yang baik, mengajarkan bagaimana cara menghormati orang yang lebih tua dan menghargai yang lebih muda, jika kami tidak menuruti perintahnya, kami dinasehati, kadang sampai diancam tidak diberikan uang jajan, oleh karena itu kami selalu menuruti perintah ayah, walau terkadang suka malas ketika disuruh, tapi kami tahu itu demi kebaikn kami, jadi kami mengikutinya dan sudah menjdi kebiasaan".

Sehubung dengan itu, Lia Armada, anak dari Bapak Dody mengatakan: "Dulu saat mamah dan papah sering bertengkar, Lia memang tidak rutin mengerjakan sholat, tetapi setelah mereka bercerai Ria makin rajin beribadah, apalagi sholat, karena Lia sadar bahwa mengerjakan sholat itu wajib, tidak ada alasan untuk tidak mengerjakannya". Berdasarkan observasi terhadap Lia, beliau merupakan remaja yang tangguh, bahkan ia sekolah sambil kerja sehingga biaya sekolah tidak pernah dia minta kepada ibunya, karena Lia tinggal dengan ibunya".

Berdasarkan observasi yang terlihat di lapangan terhadap Rina dan Rika, mereka sangat disiplin mengenai waktu, baik saat 


\section{Jurnal Kajian Gender dan Anak}

Vol. 03 No. 1 Juni 2019

Pusat Studi Gender dan Anak IAIN Padangsidimpuan

bermain atau saat kumpul dan bercerita dengan tetangga, pada saat azan tiba sang ayah langsung memanggil mereka untuk sholat.

Dampak pola asuh single parent terhadap tingkah laku beragama remaja memahami bahwa tidak semua remaja yang diasuh oleh single parent dengan pola asuh otoriter yang rutin menjalankan ibadah sholat, ternyata salah seorang informan yang orang tuanya kurang perhatian kenyataannya menjalankan ibadah sholat. Tekadang pola asuh otoriter hanya akan memaksa mereka melakukan ibadah dengan pendampingan, apabila tidak ada yang memaksa, maka sholat tidak akan dikerjakan.

b. Dampak Pola Asuh Membaca Al-Quran,

Membaca Al-Quran merupakan anjuran bagi seluruh umat muslim, agar ia memperoleh petunjuk, karena di dalam Al-Quran dijelaskan bagaimana kehidupan manusia. Dampak dari pola asuh single parent terhadap tingkah laku beragama remaja dalam membaca Al-Quran, remaja kurang pandai dalam membaca ALQuran sehingga malas untuk belajar mengaji. Salh satu remaja dari anak single parent di Desa Trans Batang Pane mengatakan yaitu anak dari bapak Jafar mengatakan bahwa sepeninggal ibunya, yaitu istri dari Bapak Jafar, Rika tidak pernah membaca Al-Quran setelah ibunya meninggal dunia, Rika mengatakan ibunya yang dulu rutin mengajari membaca Al-Quran setelah sholat" (Wawancara: 1903)

Dampak pola asuh single parent terhadap tingkah laku beragama remaja dalam membaca Al-Quran dengan menggunakan pola asuh Otoriter, seperti yang diterapkan oleh beberapa orang tua single parent, remaja terbiasa membaca Al-Quran setiap hari, walaupun pada awalnya mereka melakukannya karena paksaan, namun pada akhirnya hal itu menjadi kebiasaan dan bacaan $\mathrm{Al}$ Quran mereka semakin lancar. Sedangkan dampak pola asuh Permissif terhadap remaja dalam membaca Al-Quran, remaja kesulitan membaca Al-Quran bahkan ada yang tidak bisa membaca 
sama sekali. Sehingga remaja malu dan malas dan malu untuk datang kepengajian.

c. Pola Asuh Berbuat Baik Kepada Orang Tua

Suatu keharusan bagi seorang anak untuk berbuat baik kepada orang tua, baik itu orang tua lengkap maupun orang tua tunggal. Hal ini merupakan bukti kasih sayang dan penghormatan seorang anak kepada orang tuanya yang telah bersusah payah mengurus dan membesarkan dan mendidik anak-anaknya. Namun, tidak semua remaja mengetahui dan faham mengenai hal itu, remaja terkadang masih berani meninggikan suatu bahkan membentak orang tuanya, terutama orang tua single parent.

Setiap single parent memiliki cara dan karakter masingmasing dalam mendidik dan membesarkan anak remajanya, tergantung kapasitas dan kemampuannya. Cara pandang yang digunakan juga berbeda, tidak semua memiliki kemampuan yang mumpuni untuk mengendalikan emosi dalam mendidik anaknya, termsuk orang tua single parent. Bahkan, terkadang orang tua tidak mengetahui bagaimana memberikan pendidikan yang baik kepada anak-anaknya, karena kesibukan lain yang banyak menyita waktu.

Dari penelurusan di lapangan diketahui bahwa dampak pola asuh single parent terhadap tingkah laku beragama dalam berbuat baik kepada orang tua single parent, beberapa anak sering berlaku kasar kepada orang tuanya. Hal ini diakibatkan pola asuh permissive, yang memanjakan dan membebaskan dalam bertingkah laku, terutama dalam berbuat baik kepada orang tua, khususnya single parent.

3. Solusi yang Diperlukan Terhadap Tingkah Laku Beragama Remaja.

Meskipun single parent tidak berhasil memberikan pendidikan agama yang rutin dan maksimal dalam mengurus remaja, akan tetapi orang tua single parent tetap memberikan solusi dan upaya yang dilakukan oleh single parent terhadap tingkah laku remaja adalah: 


\section{Jurnal Kajian Gender dan Anak}

Vol. 03 No. 1 Juni 2019

Pusat Studi Gender dan Anak IAIN Padangsidimpuan

a. Memahami karakteristik remaja dan Tingkah laku

b. Turut serta dalam Pelaksanaan Sholat

c. Rutin Menyuruh Anak Melakukan Kegiatan Agama Lainnya.

d. Selalu Memantau Pergaulan Remaja

\section{E. Simpulan}

Pola asuh yang diterapkan orang tua single parent terhadap tingkah laku beragama remaja sesuai dengan fakta yang ditemukan pada umumnya dalam bentuk pola asuh otoriter, tegas dalam membimbing anak untuk mendirikan sholat dan membaca Alqur'an, agar anak tidak manja, berani dan menurut kepada orang tua, selalu membiasakan diri hidup disiplin, rajin beribadah, menjadi anak yang membantu orang tuanya kelak dan bertanggung jawab. Pola asuh tersebut memberikan dampat positif pada anak-anak single parent dilihat dari pelaksanaan shalat yang dilaksanakan secara rutin. Disamping itu juga ditemukan pola asuh yang diterapkan orang tua single parent terhadap anak terhadap tingkah laku beragama dalam berbuat baik kepada orang tua dengan pola asuh permissive, dampaknya bersifat negatif, dimana beberapa anak ditemukan sering berlaku kasar kepada orang tuanya. Hal ini diakibatkan pola asuh permissive, yang memanjakan dan membebaskan dalam bertingkah laku, terutama dalam berbuat baik kepada orang tua, khususnya single parent.

Ada solusi yang dapat diberikan untuk pola asuh terhadap tingkah laku beragama remaja yakni dengan memahami karakteristik remaja dan tingkah laku, turut serta dalam pelaksanaan sholat, rutin menyuruh anak melakukan kegiatan agama lainnya, selalu memantau pergaulan remaja. 


\section{Daftar Bacaan}

1. Agoes Dariyo, Psikologi Perkembangan Remaja, Bogor : Ghalia Indonesia, 2004

2. Faizah dan Lalu Muhsin Efendi, Psikologi Dakwah, Jakarta: Rahmat Semeste, 2006

3. Kartini Kartono, Patologi Sosial 2 ( Kenakalan Remaja), Jakarta : PT Raja Grafindo Persada.

4. Sofyan Wilis, Konseling Keluarga, Bandung : Alfabeta, 2009

5. Sri Lestari, Psikologi Keluarga, Jakarta : Kencana Pranada Media Group, 2012

6. Jalaluddin, Psikologi Agama, Jakarta : PT Raja Grafindo Persada, 2010

7. Muhammad Nur Abdul Hafizh Suwaid, Prophetic Parenting (Cara Nabi Mendidik Anak0, Yogyakarta : Pro-U Media, 2010

8. Sayyid Sabiq, Nilai-Nilai Islami, Yogyakarta : Sumbangsih Offset, 1998

9. Kusdwiratri Setiono, Psikologi Keluarga, Bandung : PT. Alumni, 2011

10. John M.Echols dan Hasan Shadly, Kamus Inggris Indonesia, Jakarta : PT Gramedia Pustaka Utama, 1976

11. Zainab Ismail, Isu Dakwah Masa Kini, Keluarga Komuniti Marginal dan Pendidikan, UKM Malaysia, Fakulti Pengkajian Islam, 2010

12. Mardani

13. Syaikh Abdul Muin, Saat Cerai Menjadi Pilihan, Solo : Pt. Aqweam Media Profetika, 2011

14. Zakiah Darajad, Ilmu Jiwa Agama, Jakarta : Bulan Bintang, 1991.

15. Wina Sanjaya, Penelitian Tindakan Kelas, Prenada Group, 2009. 